\title{
IAMJ
}

INTERNATIONAL

AYURVEDIC

MEDICAL JOURNAL

\section{EFFECT OF AYURVEDA MANAGEMENT IN SLAISHMIKI YONIVYAPAD - A CASE STUDY}

\section{$\underline{\text { Sruthi }}^{1}$, Priyanka Prem ${ }^{2}$, Kavitha B. $\mathbf{K}^{3}$}

1,23rd year P.G. scholar, Dept. of Prasuthitantra and Streeroga, Alva's Ayurveda Medical College, Moodbidri, Dakshina Kannada, Karnataka, India

${ }^{3}$ Associate professor, Dept. of Prasuthitantra and Streeroga, Alva's Ayurveda Medical College Moodbidri, Dakshina Kannada, Karnataka, India

Corresponding Author: sruthikodoth23@gmail.com

\section{https://doi.org/10.46607/iamj13p4062020}

(Published online: September 2020)

Open Access

(C) International Ayurvedic Medical Journal, India 2020

Article Received: 08/09/2020 - Peer Reviewed: 23/09/2020 - Accepted for Publication: 26/09/2020

Check for updates

\section{ABSTRACT}

Healthy habits are the best way to avoid disease. But in the chaos of a woman's daily life healthy living is not at all followed now a days. Along with overall health of a women vaginal health is also an important part. An infection or change in the normal balance of vaginal yeast and bacteria can cause inflammation of the vagina. Symptoms includes vaginal discharge, odour, itching and pain. Common types of vaginitis include bacterial vaginosis, yeast infections and trichomoniasis. According to Ayurveda gynaecological diseases are listed under Yonivyapad. Slaishmiki Yonivyapad is one among them which describes about unctuous vaginal secretion with itching and pain.

Keywords: Slaishmiki Yoni Vyapad, Vaginal discharge, Candidiasis

\section{INTRODUCTION}

In different phases of women's life, from puberty to menopause, a healthy reproductive system should be maintained and measures for doing so is elaborately mentioned in Ayurvedic Science. Because of special reproductive role, women are at the risk of some distinct female disorder. Now a day, infection related to Yoni is a common problem in females irrespective of the age or status. Many women experience 
uncomfortable vaginal infections at one time or another. Maintaining a healthy vulva and vagina will help in preventing infections and discomfort. Due to infection, there may be vaginal discharge, itching, coldness etc. and in Ayurveda, these symptoms are found in Slaishmiki Yoni Vyapad with some symptoms similar to candidial vulvovaginitis.

\section{Case Report}

A female patient aged 32 years attending the outpatient department, presenting with complaint of excessive white discharge from vagina with itching since 1 month, which is hampering her daily activities. She was also suffering from burning micturition since 20 days, pain in lower abdomen and low backache and pain during sexual intercourse. The complaints started gradually 6 months ago and was non itching for that she took some allopathic medicines and got relief. After 4 months, the symptoms recurred and became severe day by day. Now, she complaints of excessive vaginal discharge which is associated with vulval pruritus. So, for better relief she came for Ayurveda treatment.

\section{Medicinal History:}

She has taken allopathic medicine

Tab Metronidazole 200mg TID for 7 days, Same treatment was given to husband for 1 week

Tab Doxycycline 100mg for 5 days

She got relief at that time but after 4 months complaints started again.

\section{Personal History}

Occupation: Housewife, Lifestyle: Sedentary, Food habit: Irregular, Diet: Mixed, prefers fried items, Appetite: Moderate, Bowel: Constipated, Micturition: 3-4 times per day, burning sensation, Sleep: Sound, Habits: Intake of tea, 2-3 times, Exercise: Nil

Menstrual History: Menarche :14 years, she had regular menses at interval of 28-34 days, which last for 4-5 days. No other significant abnormalities detected.

Contraceptive History: No contraception Obstetric History: P1L1, Male, 10yrs, FTND

Ashtavidha Pareeksha: Nadi: 70/min, Mutra: Avishesha, Mala: Vibandha, Jihwa: Lipta, Shabda: Prakruta, Sparsha: Seeta, Drik: Prakruta, Akriti: Madhyama
Dasavidha Pareeksha: Prakriti: Kapha pradhana vata anubandhi, Vikriti: Kapha, Sara: Madhyama, Samhanana: Madhyama, Satmya: Madhyama, Satwa: Avara, Pramana: Madhyama Ahara: Abhyavaharana Shakti - Madhyama, Jaranashakti- Madhyama, Vyayama Shakti: Madhyama Vayah: Youvana

\section{General Examination}

Patient well conscious, oriented, hemodynamically stable, O/E - PR- 76/min, B.P - 110/70 mm of hg, Ht$152 \mathrm{~cm}$, Wt- 50 kg, BMI -26.8, Agni-Vishama, KoshtaMadhyama, P/A - Soft, Non tender, Pallor- Moderate anaemic, Icterus- Absent

Inspection: Vulva: Scratch marks present due to itching, pruritus present, Labia: Swollen, Discharge: White thick curdy discharge

P/s examination: Thick curdy discharge is present on vaginal wall. Vaginal wall red and inflamed with multiple small punctate strawberry spot at vagina vault. Investigations: $\mathrm{CBC}$ : WBC- 13,000 cells/cumm, $\mathrm{Hb} \%$ - $9 \mathrm{gm} \%$, FBS- $80 \mathrm{mg} / \mathrm{ml}$, PPS- $130 \mathrm{mg} / \mathrm{ml}$, HIV, HBsAg, VDRL- Negative, SG- Normal findings, Wet Mount test- Showed slings of pseudohyphae of Candida albicans surrounded by round vaginal epithelial cells

Samprapthi: Due to excessive use of Abhishyandi Ahara Vihara, Kapha and Vata (Apana Vata) vitiates. Vitiated Kapha causes Rasa Dusti as Kapha and Rakta has Ashraya-ashrayi Sambandha. Vitiated Kapha reaches Yoni/Garbhasaya. Dushti of Kapha and Rasa together cause white discharge through vagina. It causes Picchila, Sita, Kandu and dull pain in vagina with Pandu Varna Pichchila Srava leads to Slaishmiki Yonivyapad .

Samprapthi Ghataka: Dosa- Kapha, Vata; DushyaRasa, Mamsa; Srotas- Rasavaha, Artavavaha; MargaAbyanthara; Mahaboota- Pritwi, Jala, UdbavastanaPakwasaya samuttaja; Vyaktastana- Garbasaya; Samprapti prakara- Atisrava, Vimarga gamana.

Provisional Diagnosis - Candidal Vulvovaginitis ${ }^{2}$ (Candida albicans)

Treatment: $1^{\text {st }}$ visit-12-8-2019, LMP- 1-08-2019

Stanika Chikitsa

1. Yoni Prakshalana - Triphala Kashaya 


\section{Abyanthara Chikitsa}

1. Tab Chandraprabha Vati 2-0-2, After food

2. Pushyanuga Churna 3 gm, Amalaki Churna 3 gm, Sweta Parpati $250 \mathrm{mg}$ with lukewarm water, BD After food

3. Syrup Patranga Asava - 15-20 ml with equal quantity of water, BD After food.

Treatment given for 1 week with Pathyaaharavihara (avoid medicine during periods)

$\mathbf{2}^{\text {nd }}$ visit -19-08-2019

Symptoms reduced markedly.

Repeat same medicine for 1 more week.

$3^{\text {rd }}$ visit -26-08-2019

There was complete relief of symptoms, $\mathrm{P} / \mathrm{S}$ and $\mathrm{P} / \mathrm{V}$ examinations showed no discharge and healthy vulva and vagina, Triphala Kashaya Yoni Prakshalana is advised to do on alternate days for 15 days, Tab Chandrapraba Vati for 15 days 1BD After food, Satavari Gulam ${ }^{4} 1$ tsp BD for 15 days 1 teaspoon BD, After food

Pathya-apatya: She was advised to follow the follow Ahara-Vihara Pathyas as follows

\section{Ahara}

1. Drink plenty of water.

2. Eat fibrous diet, fruits, green vegetables.

3. Garlic, meat soup, rice water

\section{Vihara}

1. Keep the area clean and dry.

2. Maintain personal hygiene.

3. Wash the garments in boil water and Dettol and then dry it in sunlight.

\section{RESULTS AND DISCUSSION}

Patient was treated until all symptoms got completely reduced. As the patient has followed properly the instructions of Patya-apatya along with schedule of Yoniprakshalana, medicines the gradual recovery of symptoms were observed. At the end of treatment all symptoms were cured. Plan of treatment for this patient was based on etiopathogenesis. Along with Kapha dosha there was Rasa Dhatwagnimandya and Apana Vayu vitiation. Triphala Kashaya Yoniprakshalana is given as Shamana Chikitsa as it is Tridosha hara, Stambaka, Kashaya rasatmaka, Vrana Ropana and antiseptic. Thus, help in increasing local immunity and reduce the symptoms. Chandraprabha vati acts as Tridoshahara, Balya, Rasayana and it helps to reduce the symptoms. Pushyanuga Churna is Stambhana, indicated in various vaginal discharges and Jantukrita Doshas. Amalakai is Rasayana, supports healthy metabolism and is anti-inflammatory. Swetha Parpati is Mootrala and Vatanulomaka and helps in proper excretion of Kleda and Mala. Patrnga Asava is urinary antiseptic and astringent. It is Deepana, Panduhara, Raktadoshahara, Stambana and Sothahara. Satavari Gula is Rasayana and indicated in Sarvasrava.

\section{CONCLUSION}

Slaishmiki Yoni Vyapad can be correlated to Vulvovaginal Candidiasis. Two third of women will have at least one episode of vulvovaginal candidiasis. Depending on basic principle of Ayurveda by correcting Dosha, Dhatu, Agni disease can be treated. In this case, Ayurveda treatment helped in the balancing the Doshas and break the Samprapthi Ghataka of disease thus giving a fruitful result.

\section{REFERENCES}

1. Hemalatha Kapoorchand, A Comprehensive Treatise on Striroga, published by Chaukambha Viswabharathi, 1st edition 2018, Chapter 5, Page No 202

2. D C Duttas Textbook of Gynaecology, Published by Jaypee brothers' medical publishers, $7^{\text {th }}$ edition, 2016, Chapter 13, page no 134

3. Vagbhatas Astanga Hridayam, Translated by K.R Srikantha Murthy, Chaukamba Krishnadas Academy, Varanasy, $5^{\text {th }}$ edition,2009, Volume 3, Uttarastana, Chapter 33, Page No 323, Sloka 45-50

4. Sahasrayoga edited by K.V Krishnan vaidyar, vidyarambam publisher mullakkalalappuza, Kerala 2015, Lehya prakarana, Page no 234

\section{Source of Support: Nil Conflict of Interest: None Declared}

How to cite this URL: Sruthi K et al: Effect Of Ayurveda Management In Slaishmiki Yonivyapad - A Case Study. International Ayurvedic Medical Journal \{online\} 2020 \{cited September, 2020\} Available from: http://www.iamj.in/posts/images/upload/2528_2530.pdf 